\title{
Membrane Potential of Rat Urinary Bladder Epithelial Cells
}

\author{
Ken Hotta, Yoshimichi Yamamoto, Katsumi Imaida, * Masato Oshima, * \\ Shoji Fukushima, ${ }^{*}$ and Nobuyuki Ito* \\ Departments of Physiology and *Pathology, Nagoya City University \\ Medical School, Mizuho-ku, Nagoya, 467 Japan
}

\begin{abstract}
Summary Rat urinary bladder epithelial cells exhibited a membrane potential of about -22 (apical) and -24 (basal) $\mathrm{mV}$ in normal Krebs solution. Blockade of $\mathrm{Na}^{+}$entry through the apical membrane by $\mathrm{Na}^{+}$ depletion or administration of amiloride, or inactivation of the $\mathrm{Na}$ pump in the basal membrane by ouabain resulted in marked hyperpolarization of the epithelial cells. $N$-butyl- $N$-(4-hydroxybutyl) nitrosamine (BBN), a specific carcinogen, and saccharin, a potent enhancer of carcinogenesis, inhibited development of the $\mathrm{Na}^{+}$channel and/or $\mathrm{Na}$ pump on the bladder epithelium. This physiology may contribute to the abnormal intracellular environment leading to bladder carcinoma.
\end{abstract}

Key Words: rat urinary bladder, epithelial membrane, carcinogenesis in bladder.

The amphibian urinary bladder possesses active transport for reabsorption of $\mathrm{Na}^{+}$and possibly other electrolytes. Data on the potential difference (PD), short circuit current, and ionic fluxes across the epithelial cells of toad or turtle bladder have been reported (NAGEL et al., 1981). WickHAM (1964), LeWIS and DiAMOND (1976), and LeWIS et al. (1976) showed that the isolated mammalian (rabbit) bladder also had similar properties, i. e., transcellular $\mathrm{Na}^{+}$transport from the mucosal to the serosal side.

We examined the electrophysiological properties of rat bladder epithelial cells using microelectrodes and the nature of chemically-induced bladder carcinoma was investigated.

Urinary bladder tissues isolated from 8-10-week-old rats (Fisher 344) were mounted on a temperature controlled $\left(37^{\circ} \mathrm{C}\right)$ measuring apparatus (Fig. 1a) containing Krebs solution (in mM: $137 \mathrm{Na}^{+}, 6 \mathrm{~K}^{+}, 1.2 \mathrm{Mg}^{2+}, 2 \mathrm{Ca}^{2+}, 134 \mathrm{Cl}^{-}, 1.2$ $\mathrm{H}_{2} \mathrm{PO}_{4}^{-}, 15 \mathrm{HCO}_{3}^{-}$, and 11 glucose) bubbled with $\mathrm{O}_{2}-\mathrm{CO}_{2}(95 \%-5 \%)$. Mucosal and serosal sides were perfused separately. A microelectrode filled with $3 \mathrm{M}-\mathrm{KCl}$ solution (15-20 M $\Omega$ ) was inserted from the mucosal side with the aid of an oil-

Received for publication May 6, 1982

堀田 健, 山本喜通, 今井田克己, 大島正人, 福島正治, 伊東信行 
a
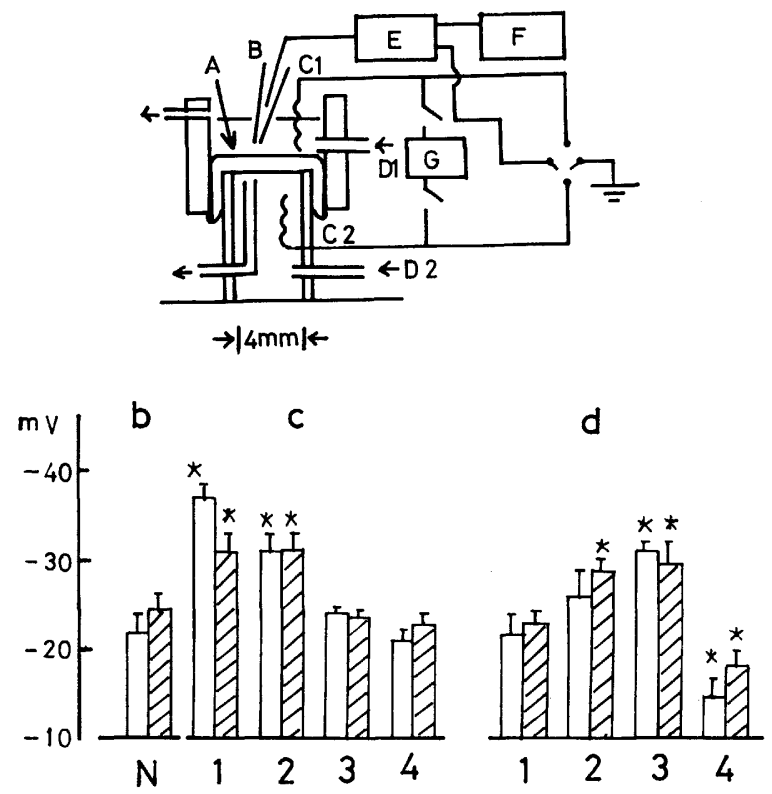

Fig. 1. a: simplified drawing of the measuring apparatus. A, bladder; B, microelectrode; C1, C2, reference electrodes placed in mucosal and serosal solutions, respectively; D1, D2, mucosal and serosal fluid supply, respectively; E, preamplifier (MEZ 8201, Nihon Kohden); F, G, high impedance voltmeter for recording potentials. b, c, d: membrane potential of epithelium of rat bladder. $\square$, apical membrane; $\llbracket$, basal membrane. Bars indicate range of S.D. ${ }^{*} p<0.01$ in respect to the corresponding control. b, control ( $n=134$, apical; $n=119$, basal); c, mucosal solution substituted; d, serosal solution substituted. $1, \mathrm{NaCl}$ to choline chloride; 2 , amiloride administration $\left(10^{-4} \mathrm{M}\right) ; 3$, ouabain administration $\left(10^{-4} \mathrm{M}\right) ; 4$, high $\mathrm{K}^{+} 50 \mathrm{~mm}$ (reduced $\left.\mathrm{Na}^{+}\right)$.

driven micromanipulator. When the microelectrode was impaled into the cell, an abrupt change of potential occurred, yet there was no noticeable change in input impedance monitored continuously during the measurement.

Six-week-old male rats were grouped into 3: group 1, $N$-butyl- $N$-(4-hydroxybutyl) nitrosamine (BBN, $0.05 \%$ in water) treated; group 2, saccharin ( $5 \%$ in diet) treated; and, group 3, control. Four rats in each group were killed at the end of 1st, 2nd, 4th, and 8th weeks after treatment and bladder tissues were prepared. Statistical significances of the differences between groups were examined using Student's $t$-test.

The rat bladder epithelial cells exhibited a membrane potential of approximately $-22.6 \pm 1.5 \mathrm{mV}$ (mean \pm S.D., $n=134$ ) and $-24.2 \pm 2.0 \mathrm{mV}(n=119)$ for the apical and basal membrane, respectively. Although transcellular PD between mucosal and serosal sides varied with the sample, the serosal potential was always more positive than the mucosal one (range $0-5 \mathrm{mV}$ ). 

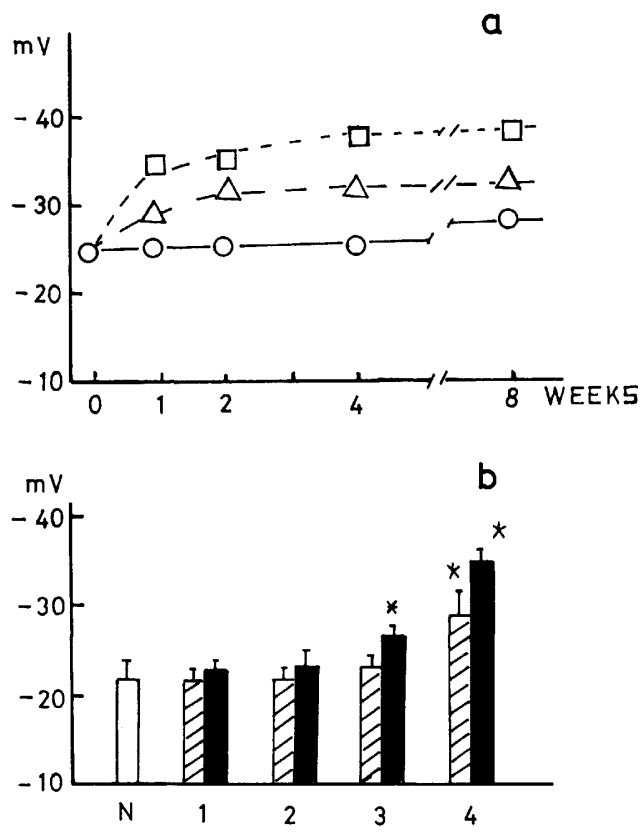

Fig. 2. Apical membrane potential change induced by treatment of rats with BBN or saccharin. a: membrane potential and period of treatment. S.D.s fall within the size of symbols. $O$, control $(n=40$, each point); $\Delta$, saccharin ( $5 \%)$ in diet; $\square$, BBN $(0.05 \%)$ in water. b: dependence on chemical concentrations (4 weeks treatment). Bars indicate range of S.D.; ${ }^{*} p<0.01$ in respect to the corresponding control. $\square$, control $(n=120)$; ש, saccharin (S); $\mathrm{m}, \mathrm{BBN}(\mathrm{B}) . \quad 1,0.04 \mathrm{~S}$ or $0.001 \mathrm{~B}(\%) ; 2,0.2 \mathrm{~S}$ or $0.005 \mathrm{~B}(\%) ; 3,1.0 \mathrm{~S}$ or $0.01 \mathrm{~B}(\%) ; 4,5.0 \mathrm{~S}$ or $0.05 \mathrm{~B}(\%)$.

The effects of $\mathrm{Na}^{+}$deficiency, addition of amiloride or ouabain, and high $\mathrm{K}^{+}$ on the membrane potential were investigated. When the mucosal side of the membrane was exposed to $16.2 \mathrm{mM}-\mathrm{Na}^{+}$solution $(\mathrm{NaCl}$ was replaced with choline chloride), there was a drastic hyperpolarization of the apical membrane $(-36.8 \pm$ $1.2 \mathrm{mV}$ ), whereas no such change occurred with exposure of the serosal side to Na-deficient solution. Amiloride, a $\mathrm{Na}^{+}$channel blocker (BENTLEY, 1968), had an effect similar to that seen in the $\mathrm{Na}^{+}$deficient solution (Fig. 1). On the other hand, ouabain induced a marked hyperpolarization of the apical membrane only when applied from the serosal side. Hyperpolarization lasted for at least $15 \mathrm{~min}$, and a gradual depolarization followed. High- $\mathrm{K}^{+}$solution applied from the serosal side reduced the membrane potential (Fig. 1) and the changes in the potential were completely reversible when the bathing solutions were replaced by normal Krebs solution.

Figure 2 shows the change in the apical membrane potential induced by pre-treatment of animals with BBN or saccharin. Apical membrane potential of the bladder cells became increasingly negative with extension of the periods of 
treatment (Fig. 2a) and a plateau was evident at the 4th week. These changes were dose dependent (Fig. 2b). The membrane potentials of bladder cells from BBN treated rats were not affected by replacement of $120.8 \mathrm{mM}-\mathrm{NaCl}$ with equimolar choline chloride in the solution of the mucosal side or by addition of ouabain to the solution of the serosal side after 4 weeks of pre-treatment (data not shown). In these pathological cells there was a negligible transcellular PD, as deduced from a small number of measurements.

The results on apical membrane potential obtained here are consistent with findings in case of the rabbit bladder, reported by Lewis et al. $(-25$ and $-40 \mathrm{mV}$, normal and $\mathrm{Na}^{+}$deficient, 1976), however, basal membrane potential and transcellular PD observed in our study were much smaller than their values $(-41 \mathrm{mV}$ and more than $20 \mathrm{mV}$ serosal positive). Reasons for the discrepancies may be: (1) leaky intercellular structures for ions in the rat bladder or (2) increased ionic conductance due to the edge damage when mounting the specimen in the apparatus, as pointed out by Lewis et al. (1976). As the rat bladder is so small, the area exposed to the measurement was $0.12 \mathrm{~cm}^{2}$, while that for the rabbit bladder used by LEWIS and DiAmond (1976) was $2 \mathrm{~cm}^{2}$. Therefore, effects related to the damaged area may be more considerable in case of rat tissue than in the rabbit. The membrane potential of rat epithelial cells appears to consist of $\mathrm{K}^{+}$diffusion and partly Na pump potentials, as suggested by Lewis and Diamond (1976). High permeability to $\mathrm{Na}^{+}$through the apical membrane may reduce the membrane potential calculated from the $\mathrm{K}^{+}$equilibrium potential when intracellular $\mathrm{Na}^{+}$ concentration is kept at low levels. Therefore, the hyperpolarization induced by reduced $\mathrm{Na}^{+}$influx (which is caused by $\mathrm{Na}^{+}$depletion or by amiloride) may be evidence for the significant involvement of $\mathrm{Na}^{+}$diffusion potential in the apical membrane potential.

BBN and saccharin, a specific carcinogenic factor and an enhancer of bladder cancer, respectively, induced marked morphological changes on the surface of epithelial cells, i. e., swelling and development of microvilli (Iто et al., 1969; SHIRAI et al., 1977). Treatment of animals with these chemicals induced marked hyperpolarization of apical membrane of the epithelial cells. BBN and saccharin had no effect when added directly to the bathing solutions, indicating no immediate interactions between the ionic channels or active pump in the membrane and the chemicals. Therefore these chemicals may inhibit formation of the specific $\mathrm{Na}^{+}$channel on the apical membrane during differentiation of the cell. The intracellular ionic environment is modified considerably under these conditions (HANDLER et al., 1972). Thus, in the course of cell differentiation, an abnormal occurrence such as carcinogenesis may occur.

This work was supported in part by Grants for Cancer Research, Nos. 56010062 and 56010076 from the Ministry of Education, Science and Culture of Japan. We thank M. Ohara for reading the manuscript. 


\section{REFERENCES}

Bentley, P. J. (1968) Amiloride: A potent inhibitor of sodium transport across the toad bladder. J. Physiol. (Lond.), 195: 317-330.

Handler, J. S., Preston, A. S., and Orloff, J. (1972). Effect of aldosterone, ouabain and amiloride on toad bladder epithelial cells. Am. J. Physiol., 222: 1071-1074.

Ito, N., Hiasa, Y., Tamai, A., Okajima, E., and Kitamura, H. (1969) Histogenesis of urinary bladder tumors induced by $N$-butyl- $N$-(4-hydroxybutyl) nitrosamine in rats. Gann, 60: 401-410.

Lewis, S. A. and Diamond, J. M. (1976) $\mathrm{Na}^{+}$transport by rabbit urinary bladder, a tight epithelium. J. Membr. Biol., 28: 1-40.

Lewis, S. A., Eaton, D. C., and Diamond, J. M. (1976) The mechanism of $\mathrm{Na}^{+}$transport by rabbit urinary bladder. J. Membr. Biol., 28: 41-70.

NAGEL, W., DuRHAM, J. H., and BrodSKY, W. A. (1981) Electrical characteristics of the apical and basal-lateral membranes in the turtle bladder epithelial cell layer. Biochim. Biophys. Acta, 646: 77-87.

Shirai, T., Murasaki, G., Tatematsu, M., Tsuda, H., Fukushima, S., and Ito, N. (1977) Early surface changes of the urinary bladder epithelium of different animal species induced by $N$-butyl- $N$-(4-hydroxybutyl) nitrosamine. Gann, 68: 203-212.

WickHAM, J. E. A. (1964) Active transport of sodium ion by the mammalian bladder epithelium. Invest. Urol., 2: 145-153. 